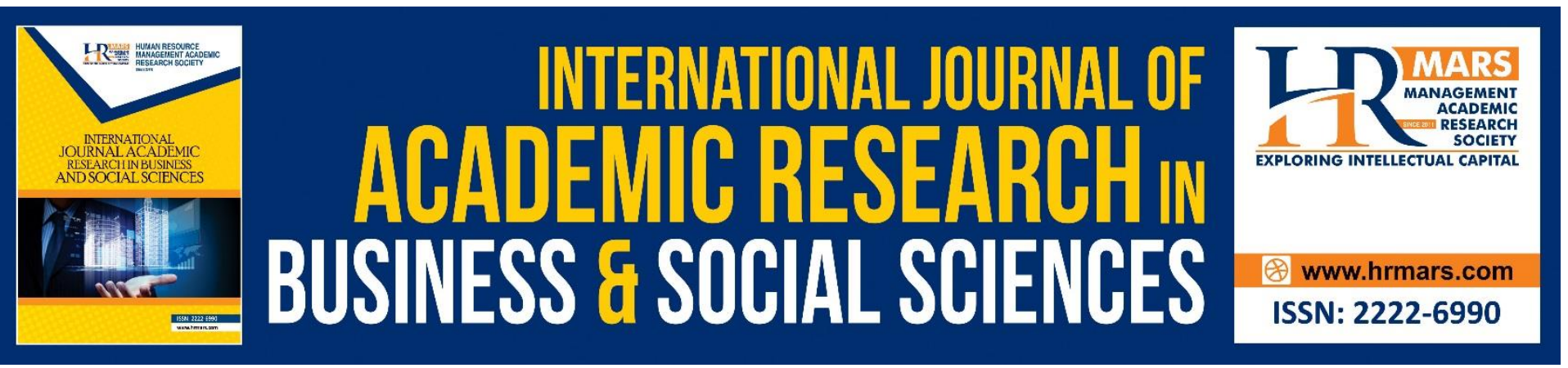

\title{
Factors Hindering Undergraduate Students from Starting a Business While Studying
}

Zurina Binti Patrick, Adriana Mohd. Rizal, Ong Choon Hee, Mahaza Mahadi, and Suzilawati Kamarudin

To Link this Article: http://dx.doi.org/10.6007/IJARBSS/v9-i1/5421

DOI: $\quad 10.6007 /$ IJARBSS/v9-i1/5421

Received: 20 Dec 2018, Revised: 19 Jan 2019, Accepted: 30 Jan 2019

Published Online: 12 Feb 2019

In-Text Citation: (Patrick, Rizal, Hee, Mahadi, \& Kamarudin, 2019)

To Cite this Article: Patrick, Z. B., Rizal, A. M., Hee, O. C., Mahadi, M., \& Kamarudin, S. (2019). Factors Hindering Undergraduate Students from Starting a Business While Studying. International Journal of Academic Research in Business and Social Sciences, 9(1), 455-468.

\section{Copyright: @ 2019 The Author(s)}

Published by Human Resource Management Academic Research Society (www.hrmars.com)

This article is published under the Creative Commons Attribution (CC BY 4.0) license. Anyone may reproduce, distribute, translate and create derivative works of this article (for both commercial and non-commercial purposes), subject to full attribution to the original publication and authors. The full terms of this license may be seen at: $\underline{\text { http://creativecommons.org/licences/by/4.0/legalcode }}$

Vol. 9, No. 1, 2019, Pg. 455 - 468

Full Terms \& Conditions of access and use can be found at http://hrmars.com/index.php/pages/detail/publication-ethics 


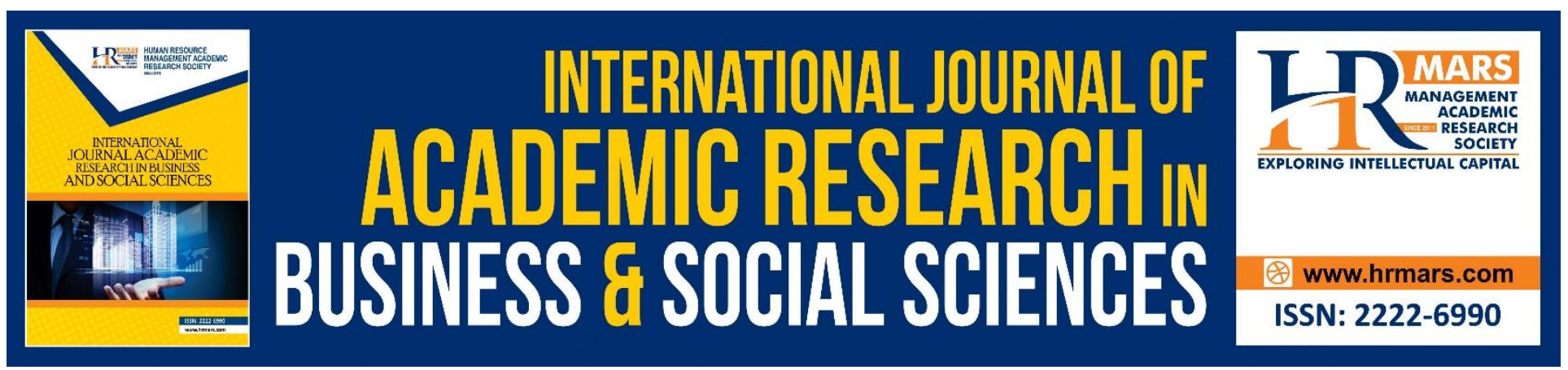

\title{
Factors Hindering Undergraduate Students from Starting a Business While Studying
}

\author{
Zurina Binti Patrick¹, Adriana Mohd. Rizal², Ong Choon Hee³, \\ Mahaza Mahadi ${ }^{4}$, and Suzilawati Kamarudin ${ }^{5}$ \\ 1,2,3,4,5 Azman Hashim International Business School, Universiti Teknologi Malaysia Johor, Malaysia \\ Email: adrianamohdrizal@gmail.com
}

\begin{abstract}
Studies on entrepreneurship intention in Malaysia focused more on postgraduate students than undergraduate students. The students' entrepreneurial intention, particularly factors contributing to the undergraduate students' decisions not to become entrepreneurs were not well discussed. Small and Medium Enterprises (SMEs) have long been a positive factor to the improvement of the country's economy and the nation's well-being. Although there are many government assistances, there are still many undergraduate students who choose not to be involved in business or run their own business. Research on factors hindering the undergraduate students from starting a business while studying is important as the future working environment largely depends on the enthusiasm, agility, and creativity of these generations. The objective of this study is to review the entrepreneurship intention literature within the context of business start-up among university students. This study also proposes a conceptual model to increase the understanding of the factors hindering undergraduate students from starting a business while studying. This model, which enhances knowledge of entrepreneurship intention among undergraduate students, enriches the theory of Psychological School of Thought and Social Networking Theory in entrepreneurship intention research.
\end{abstract}

Keywords: Small and Medium Enterprises (SMEs), entrepreneurship intention, entrepreneur, and undergraduate students

\section{Introduction}

Small and Medium Enterprises (SMEs) have long been a contributing factor to the improvement of the country's economy and the nation's well-being (Hoelscher and Elango 2012; Hatten 2006). Developing countries face poverty, unbalanced development, and unemployment, and among these problems, unemployment is the most blazing problem (Dev and Mahajan 2003). To increase the national economy, new enterprises are crucial in generating national income and creating jobs. Ninety-seven percent of the business foundations in Malaysia are small and medium enterprises, it represents sixty-five percent of the country's employment (Malaysian SMEs 2017). Based on the 
Eleventh Malaysian Plan (11MP), the development of small and medium enterprises has become one of the government concerns (Malaysian SMEs 2017) with the aim to enhance the contribution of small and medium enterprises to the Malaysian economy by 2020. Students' project components and entrepreneurship at university level becomes an initial platform in Malaysia in providing financial and non-financial assistance to the students; this include government funding, physical infrastructure, and business advisory services (Manjit et al. 2011). According to the Malaysian SMEs (2017), the government has used various approaches to support the youth in entrepreneurial activities such as providing bank credits, business access to funding (capital) with a specific end goal to influence students' career options. Other than that, industry trainings from different enterprise programmes were also offered to the undergraduate students to exploit untapped business opportunity (Olugbola 2017). Although there are many government assistances, there are still many undergraduate students who choose not to be involved in business or start their own businesses. This trend affects the initial number entrepreneurship activities in Malaysia which is lower than the other parts of the developing countries (Zamberi-Ahmad and Xavier 2012). This problem causes unemployment among graduates and one of the solutions is them to create their own jobs or start their own businesses (Singh Sandhu et al. 2011). On the issue of student's intention to start a business, uncertain global business environment presents new challenges and opportunities to small and medium enterprises (Radzi et al. 2017). Furthermore, it is essential to focus more on the undergraduate students as future working environment largely depends on the enthusiasm, agility, and creativity of these generations (Kvedaraite 2014). Banerji et al. (2014) found that in the aftermath of the Global Financial Crisis (GFC), the global youth population has been negatively affected by the deep recession, the ensuing environment of prolonged and shallow economic recovery and lackluster job growth. As for Malaysia, the youth unemployment rate in the country reached 11 percent in 2015, more than three times higher than the national unemployment rate of 3 percent (Dian-Hikmah and Mahyuddin 2016). In the quest of developing a national economy, the goal is to reduce the unemployment rate especially among the youth (Kuriakose and Joseph 2015). Undergraduate students at Malaysian public universities were chosen due to the university's plan to develop more entrepreneurial activities to assist small and medium enterprise to achieve international standards. To align with the government agenda on the development of entrepreneurship in Malaysia (Manjit et al. 2011), universities encourage the students to create new start-ups. In turn, universities would provide consultancy and advisory in the areas of finance, business and business model for its staffs and students who are engaged in the entrepreneurial activities and programmes that are related to innovation and technology. The undergraduate who want to start a business, however, should have the intention to do so; this is one of the essential processes (Lee and Wong 2004). Previous studies on entrepreneurship intention emphasized mainly on the postgraduate students (Tucker and Selcuk 2009; Trivedi 2017; Laily et al. 2017) than the undergraduate students. Research on entrepreneurship intention among undergraduates, particularly the factors hindering student's intention to start a business while studying is important to understand their needs in creating their own jobs and meeting job satisfaction (Kerr and Armstrong-Stassen 2011). To remedy this gap, there is a need to focus on the factors that hinder the undergraduates to become entrepreneurs albeit various government's supports. Such outcomes are important especially in emerging economy context (Smallbone et al. 2014). The objective of this study is to review the entrepreneurship intention literature within the 
INTERNATIONAL JOURNAL OF ACADEMIC RESEARCH IN BUSINESS AND SOCIAL SCIENCES

Vol. 9, No. 1, Jan, 2019, E-ISSN: 2222-6990 @ 2019 HRMARS

context of business start-up among university students. This study then proposes a conceptual model to increase the understanding of the factors hindering undergraduate students from starting a business while studying.

\section{Literature Review}

\section{Entrepreneurship Intention}

Research on entrepreneurship intention gains interest of the researchers in the field due to its importance to the development and the creation of new businesses for many countries including Malaysia (Michael et al. 2016; Francisco and Alain 2015; Rauch and Hulsink 2015; Merle et al. 2014; Sivarajah and Achchuthan 2013). Intentions play a big role in the decision to start a new business (Ozaralli and Rivenburgh 2016). Desire also occupies a major place in entrepreneurship (Cardon et al. 2005). According to Luca and Cazan (2011), innovation and creativity are important characteristics for entrepreneurship. Entrepreneurship intention is the deliberate state of mind that precedes action and push through in the direction of establishing the business as a target (Shane and Venkataraman 2000). Entrepreneurial intention can also predict involvement among students in entrepreneurship and explain students' decisions to start their own businesses (Ariff et al. 2010). Previous studies have linked individual traits with entrepreneurial intentions (Brandstätter 2011; Solesvik 2014), and various aspects of leadership (Vecchio 2003). Leadership skill has been associated with attributes such as individual's motivation, uncertainty tolerance, and ability to take the risk (Madrigal et al. 2012). Entrepreneurship intention can be defined as the intention and encouragement that a person has to start a business (Dinis et al. 2013). Other studies define entrepreneurship intention as an impression of the condition of the mind and prompts individuals to take up independent work as opposed to being employed (Karimi et al. 2016). In short, entrepreneurship intention is conceptualized as actions and obligations of individuals who are motivated and encouraged to start a business (Gerba 2012). Not all undergraduate wants to become an entrepreneur, they have different opinions in selecting their careers with some choose entrepreneurship as a career and some go for employment (Aslam and Hasnu 2016). Thus, undergraduate students' decisions should be analyzed in order to understand which factors hinder their intentions to start-up a business (Aslam and Hasnu 2016).

\section{University Support}

50 percent of new businesses with less prepared entrepreneurs failed in their first year (Robb and Fairlie 2006). Based on this fact, it is a very important for young students or entrepreneurs to identify their interests while still studying at the university to take relevant courses to help them learn on how to formulate and implement the business strategy (Turker and Selcuk 2009). Apart from the addition of knowledge about starting a business, university support may also help students plan businesses in a competitive and volatile economy more effectively (Gelaidan and Abdullateef 2017). On that note, entrepreneurship education has become a serious matter for course developers, university administrators, policymakers, and researchers (Kuratko 2005). According to Drucker (1985), entrepreneurship is a discipline that can be learned. All this require an innovative and creative individual to start a business to capture a golden opportunity (Wang and Wong 2004; Turker and Selcuk 2009). The development of student entrepreneurs is important for the development of the 
nation. University-based entrepreneurship education and programmes promise to support a range of potential entrepreneurial outcomes (Nabi and Liñán 2011; Rideout and Gray 2013) such as improved students' knowledge, attitudes and entrepreneurship skills (Greene and Saridakis 2008). Education is important as it provides exposure and early development of entrepreneurship which can lead to persistence in the intent of starting a business (DeGeorge et al. 2008). Among the strategies adopted by the Malaysian Government to develop resilient, competitive and excellent young entrepreneurs is through education and entrepreneurship trainings (Yusof 2009; Tenth Malaysian Plan 2006-2010, 2013), implemented holistically to enhance knowledge, skills, and intellectual capital. Scholars have recognized the importance of entrepreneurship education as it influences students' intentions to become entrepreneurs (Franke and Lüthje 2004; Schwarz et al. 2009; Packham et al. 2010). Exploring the real factors responsible for shaping intention of students to start their own business is fundamental for building the programmes and policies aimed at promoting entrepreneurial behavior (Frank and Lüthje 2004; Bakotiü and Kružiü 2010). Saeed et al. (2015) stated that knowledge regarding entrepreneurship is central and very important to student entrepreneurship. Other researchers also argued that university plays important roles in providing entrepreneurship education to students. Various trainings and supports have been recognized as one of the motivation factors for entrepreneurship intention among university students (Zhao et al. 2005). This concur with previous studies that early education-related entrepreneurship at university level is effective to positively influence the student's feeling to start a new venture (Martin et al. 2013).

\section{Government Mission to Attract More Potential Entrepreneurs in Malaysia}

Some programmes are organized under government agencies with funds available to those who want to start a business or expand their current businesses. Soft Loan Schemes for Service Sector (SLSSS) offers financing assistance for start-ups or new companies' expansions, upgrading and diversifying existing services by increasing productivity and efficiency in service delivery. Soft Loan Schemes for SMEs (SMSMs) help SMEs operating on unlicensed premises to transfer their businesses to licensed industrial or licensed premises and assist these businesses in terms of improving their competitiveness, efficiency, and productivity through the implementation of Information and Communication Technologies (ICT) in business management and operations. The Graduate Entrepreneur Fund (GEF) is a special fund offering to Malaysian graduates to venture into entrepreneurship. Young Entrepreneurs Fund is to attract more young people aged 18-30 years to apply for funding to start a business. Bumiputera Enterprise Enhancement Programme (BEEP) aims to develop the potential Bumiputra small and medium businesses through aid packages including financial assistance and advisory services. SME Emergency Fund (SMEEF) is established to assist small and medium enterprises (SMEs) which adversely affected by natural disasters. This Fund provides soft loan financing for purchases of machinery and equipment, refurbishment of premises and working capital requirements such as purchases of raw materials and consumables. Business StartUp Fund (BSF) is responsible for facilitating the growth of technology entrepreneurs and new startups. TEKUN financing offers funding, entrepreneurial information and business opportunities from micro to small and medium businesses (SMEs) with the aim of developing an efficient, innovative and progressive entrepreneurial community. TEKUN financing offers microfinance facilities for working 
capital requirements to help small Bumiputera entrepreneurs in the implementation of new businesses and existing projects. In the Tenth Malaysia Plan, the government is committed to developing creativity through such businesses to stimulate entrepreneurship, applying elements of innovation in the school curriculum, focusing on research and development (R\&D) and increasing the availability of risk capital (Tenth Malaysian Plan 2006-2010, 2013). The government provides bigger funding for venture capital especially based on Mudharabah (risk sharing) through joint investment with the private sector. The government increases R\&D spending during the $10 \mathrm{MP}$ period through sectoral bigger funds for public and supports business Private Sector R\&D (11MP, 2010). In the Economic Census Report 2016, ninety-eight-point five percent of business establishments in Malaysia are SMEs. The SME advancement programmes are additionally reinforced in the Eleventh Malaysia Plan, which is from 2016 to 2020, in accordance with the SME Masterplan targets and towards accomplishing a high-salary country by 2020 (Malaysia SMEs 2017). The 11MP concentrates on profitability, development, business, and comprehensiveness. Likewise, to improve monetary development, new projects are additionally being actualized for the last forty percent of the pyramid generally including self-employed micro-entrepreneurs to raise their earnings and standard of living (Malaysian SMEs 2017). This is to guarantee that the nation is progressing into an advanced and comprehensive country in the genuine sense. The government proceeds to screen and measure the adequacies and effects of these projects through a results-based approach (SME Report 2016). Despite the support of all government agencies, the number of students starting a business is still not much, especially for undergraduates. It is therefore important to examine the factors hindering the start of business among undergraduates.

\section{Factors Hindering Business Start-up among Undergraduates}

In this study, the psychological of thought theory and social networking theory are used to examine the entrepreneurship intention among undergraduate students at Malaysia public universities. Entrepreneurial psychological is a piece of the entrepreneurial activity that is vital in planning procedures to decide the achievement of the association (Dess et al. 1997). According to Churchill and Lewis (1986), the psychological theoretical context is used more widely to determine one's personal measure of entrepreneurship intention. Factors that affect an individual's decision on business start-up differ from many aspects (Adrimag and Martins 2004). In this context of the study, the undergraduate might face few different factors that hinder them from starting a business while studying although the government has provided financial and non-financial assistance. According to Ramayah and Harun (2005), one of the difficult weaknesses to start a business is lack of capital access. In addition, when directly questioned in interviews, potential entrepreneurs said that raising capital is their principal problem (Blanchflower and Oswald 1998). Ven (2007) revealed that capital is one of the critical factors which indirectly affect the establishment of new business, and accessibility of industry or market information that is important to a new business creation. Monetary assets empower business visionaries to support product development, deploy marketing campaigns, and recruit and hire capable workers (Huang and Knight 2017). However, financial resources alone are not enough to build a business (Huang and Knight 2017). Access to partners and consultants or advisors as a social resource greatly helps in reinforcing business ideas (Coase 1937; Connor and Prahalad 1996; Grant 1996; Kogut and Zander 1992). Social networks are expected to influence 
INTERNATIONAL JOURNAL OF ACADEMIC RESEARCH IN BUSINESS AND SOCIAL SCIENCES

Vol. 9, No. 1, Jan, 2019, E-ISSN: 2222-6990@ 2019 HRMARS

entrepreneurial success because they give access to resources (Jenssen and Koenig 2002). According to Aldrich and Ruef (2006), at least half of the new efforts have fallen in five years, clearly showing unpredictable entrepreneurial ventures. To reduce the probability of failure, and succeed in launching a new business, entrepreneurs must secure a diverse set of resources (Van de Ven et al. 1999). Nahapiet and Ghoshal (1998) defined social capital as the "sum of actual and potential resources embedded within, available through, and derived from the network of relationships possessed by individuals". In practice, developing a network that provides or facilitates access to the necessary business resources that is essential to succeed and achieve the desired results, is often through a broker (Burt 2005). Vissa (2012) suggests that strong social capital is growing through an entrepreneurs' network expansion behaviours, which involve reaching out to new friends or contacts and establishing interpersonal knowledge of them. Entrepreneurs have the greater part of the assets and abilities to make and develop their ventures (Granovetter 1995). Many researchers believed that in order to access financial and other resources, entrepreneurs often rely on personal social networks to facilitate their activities (Granovetter 1985; Granovetter 1995; Jack and Anderson 2002; Greve and Salaff 2003). More specifically, social networking comprises innovative cross organizations that work together on 'the dual mission of financial sustainability and social purpose' (Doherty et al. 2014). Other innovative research by Singh Sandhu et al. (2011) also stated that social and organizational networks are also important for new start-ups. Social networking is an important part of the social capital of entrepreneurs and it also serves to increase human capital returns such as intellect and education (Burt 1997). Human and social capital also found to have an impact on small business performance (Singh Sandhu et al. 2011). Singh Sandhu et al. (2011) reveals that social networking in Malaysia is an important factor in influencing the small and medium enterprises activities and such lack of social networking can hinder entrepreneurship intentions. In the Malaysian case, and at the risk of over-speculation, one might say that on an individual level, attitudes toward new business creation have been beforehand isolated along racial lines (because of the distinguishing proof of race with financial action), in spite of the fact that the circumstance is starting to change as the entire of Malaysian culture starts to modernize and social rebuilding starts to produce results (Ariff and Syarisa-Yanti 2002). Previous studies have demonstrated that risk and risk-taking capabilities have been identified as key features of entrepreneurs (Van Praag and Cramer 2001; Hvide and Panos 2014; Hamböck et al. 2017). An individual who starts a business to serve both self-interests and aggregate interests by addressing unmet social and ecological needs are generally referred to as sustainable entrepreneurs (Hoogendoorn et al. 2017). Innovative research by Wang and Wong (2004) found out that fear of risk was a factor affecting the entrepreneurial intention. Additionally, researchers have argued that different types of entrepreneurs face different types of risks (Shaw and Carter 2007; Block et al. 2015). For an instant, Shaw and Carter (2007) suggest that social entrepreneurs fear personal risks of a non-financial type, such as the risk of losing local credibility or their network of personal relationships. According to Hofstede (1980), the society in Malaysia is perceived as having a high level of uncertainty avoidance. As a result, it can be assumed that Malaysian are risk averse especially when it comes to entrepreneurship (Hofstede and Bond 1988). It is obvious that the process of entrepreneurship initiates the demand for work assignments, social obligations and interpersonal relations (Singh Sandhu et al. 2011). While creating and running new businesses, individuals are exposed to high level of stress (e.g., unpredictable environments, rapid change, 
personal responsibility for others, work overload) (Baron et al. 2016). The uncertain or unknowns pose anxiety that puts pressure on many people, contrary to the universal fear caused by known or understood threats (Singh Sandhu et al. 2011). High level of stress may interfere with entrepreneurs' capacity to perform several tasks crucial to the success of their new ventures (Baron et al. 2016). Henderson and Robertson (1999) found that students who did not intend to become entrepreneurs want to live a family life and assume that entrepreneurship involves too many works. Because Malaysian society has a high degree of uncertainty avoidance (Hofstede, 1980), Singh Sandhu et al. (2011) assume that Malaysians are more averse to stress, therefore, they have a high degree of uncertainty avoidance.

\section{Conceptual Framework}

There are many studies on entrepreneurship intention. Numerous factors that will influence entrepreneurship intention have been discussed individually. This study's conceptual framework is developed based on the factors hindering business start-up among undergraduates as discussed earlier in section 2.4. Lack of resources, lack of social networking, fear of risk and aversion to stress are among the factors that affect the entrepreneurship intention among the undergraduates. The conceptual framework for the study is in figure 1.

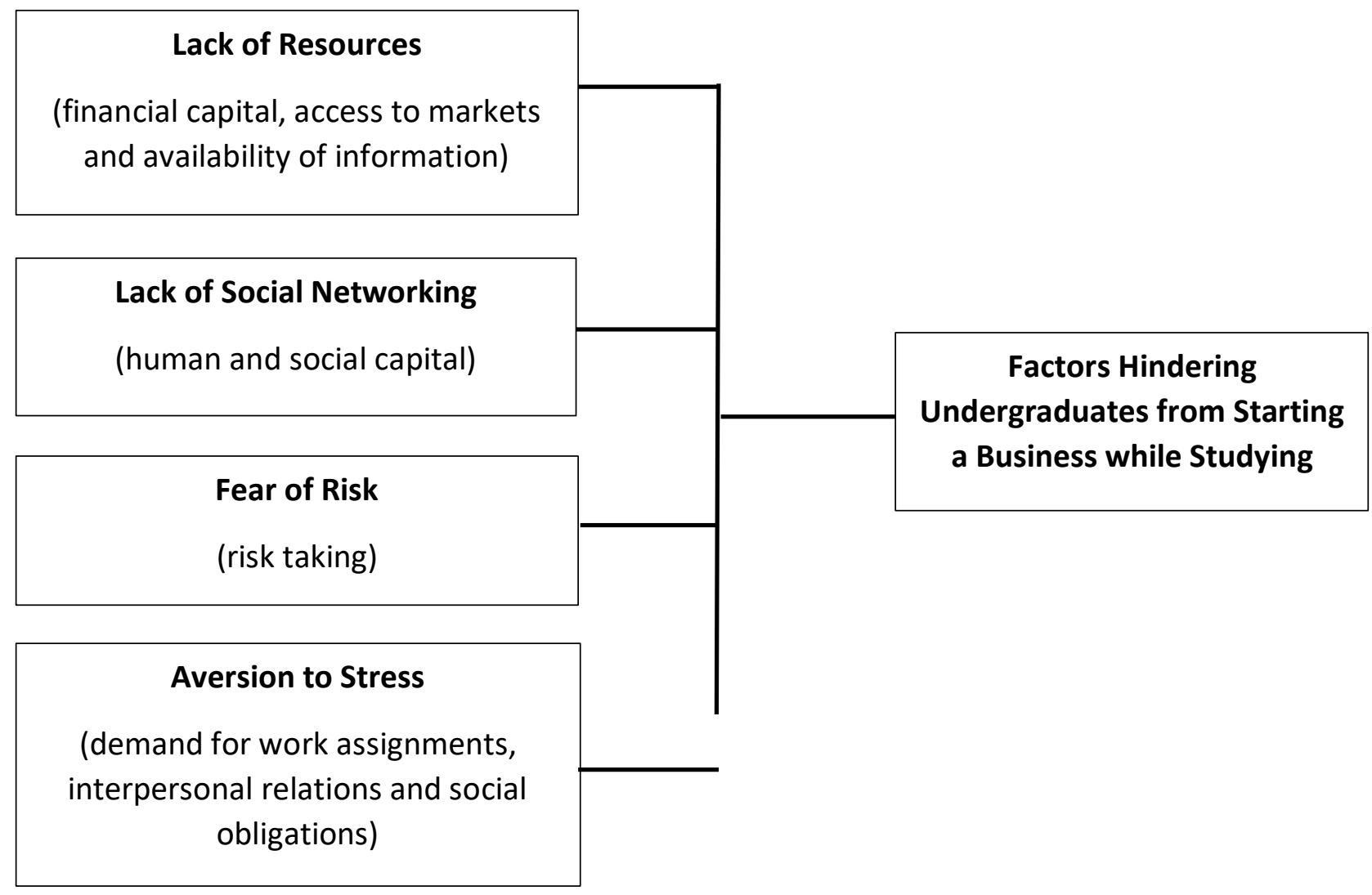

Figure 1: Factors that Hinder Undergraduate from Starting a Business while Studying 


\section{Conclusion and Future Research}

Previous researchers have highlighted the need for more research on entrepreneurship intention, particularly the factors that affect student's intention to start a business while studying. Manjit et al. (2011) conducted a study on new business start-up to understand the factors affecting entrepreneurship intention among postgraduate students in Malaysia and take the knowledge as part of learning for the business start-up. The issue of lack participation of students in business, especially the undergraduate students, raises the question of whether entrepreneurship education at university level is lacking or the government policy needs to be reviewed to inspire students to take up entrepreneurship. This study builds upon the extant literature on entrepreneurship intention among students and proposes a conceptual framework to identify the factors hindering the undergraduate students from starting a business while studying. The study further broadens the understanding of entrepreneurship intention and the contributing factors that affect the undergraduate students' decisions not to become an entrepreneur. Utilizing a qualitative method, the study could be expanded into the multiple-case study with undergraduate students who have already started their business while studying. The case study design could increase the understanding of the reasons why some of the undergraduate students do not want to start a business while studying, despite having government financial and non-financial supports. The semi-structured interviews will be developed and utilized during the in-depth interviews section with the undergraduate students. This is to ensure that the undergraduate students give the right and full information regarding their entrepreneurship intention.

\section{Acknowledgement}

The study was supported by Universiti Teknologi Malaysia and Malaysian Ministry of Higher Education under Research University Grant Tier 1 (RUG of UTM), No.: Q.K130000.2563.16H52, entitled - Exploring Municipal Solid Waste Incineration Plant Operations in Malaysia.

\section{Corresponding Author}

Adriana Mohd Rizal

Azman Hashim International Business School, Level 10, Menara Razak, Universiti Teknologi

Malaysia, Jalan Sultan Yahya Petra, 54100 Kuala Lumpur.

E-mail: adriana.kl@utm.my

\section{References}

Adrimag, C. and Martins, S. (2004). Projects and entities in the activity and projects. Retrieved from Adrimag: www.adrimag.com.pt/downloads

Aldrich, H. E., and Ruef, M. (2006). Organizations evolving. London: Sage Publication Inc.

Ariff, A. H. M., Bidin, Z., Sharif, Z., \& Ahmad, A. (2010). Predicting entrepreneurship intention among Malay University Accounting students in Malaysia. UNIFAR e-journal, 6(1).

Ariff, M. and Syarisa Yanti, A.B. (2002). Strengthening Entrepreneurship in Malaysia. Malaysian Economic Outlook: 1st Quarter 2002 update, Proceedings of the 7th Corporate Economic Briefing, 2002, Malaysian Institute of Economic Research (MIER), 1-22. 
INTERNATIONAL JOURNAL OF ACADEMIC RESEARCH IN BUSINESS AND SOCIAL SCIENCES

Vol. 9, No. 1, Jan, 2019, E-ISSN: 2222-6990 @ 2019 HRMARS

Aslam, S. and Hasnu, S. (2016). Issues and constraints perceived by young entrepreneurs of Pakistan. World Journal of Entrepreneurship, Management and Sustainable Development, 12(1), 50-65.

Bakotiü, D., and Kružiü, D. (2010). Students' perceptions and intentions towards entrepreneurship: The empirical findings from Croatia. izlazi u samo elektronibkom izdanju: NE.

Banerji, A., S. Saksonovs, H. Lin, and R. Blavy. (2014). Youth Unemployment in Advanced Economies in Europe: Searching for Solutions. Washington DC: IMF Staff Discussion Note.

Baron, R., Franklin, R. and Hmieleski, K. (2016). Why Entrepreneurs Often Experience Low, Not High, Levels of Stress. Journal of Management, 42(3), 742-768.

Blanchflower, D.G. and Oswald, A.J. (1998). What makes an entrepreneur? Journal of Labor Economics, 16(1), 26-60.

Block, J., Sandner, P., and Spiegel, F. (2015). How do risk attitudes differ within the group of entrepreneurs? The role of motivation and procedural utility. Journal of Small Business Management, 53(1), 183-206.

Brandstätter, H. (2011). Personality aspects of entrepreneurship: a look at five meta-analyses. Personality and Individual Differences, 51(3), 222-230.

Burt, R. (1997). The contingent value of social capital. Administrative Science Quarterly, 42, 339-65.

Burt, R. S. (2005). Brokerage and closure: An introduction to social capital. Oxford university press.

Cardon, M. S., Zietsma, C., Saparito, P., Matherne, B. P., and Davis, C. (2005). A tale of passion: New insights into entrepreneurship from a parenthood metaphor. Journal of Business Venturing, 20(1), 23-45.

11MP (2010). Chapter 1, a 10th Malaysia Plan, 2011-2015. Putrajaya: Economic Planning Unit of Prime Minister's Department.

SME Report (2016). Chapter 5, SME and Entrepreneurship Development Programmes. SME ANNUAL REPORT 2015/16.

Churchill, N.C. and Lewis, V.L. (1986). Entrepreneurship Research. Cambridge, MA: Ballinger Publishing.

Coase, R. (1937). The nature of the firm. Economica, 4, 386-405.

Connor, K. R. and Prahalad, C. K. (1996). A resource-based theory of the firm: knowledge versus Opportunism. Organization Science, 7(5), 477-501.

DeGeorge, Michel, J., \& Fayolle., A. (2008). Is Entrepreneurial Intention Stable Through Time? First Insights from a Sample of French Students. International Journal of Entrepreneurship and Small Business, 5(1), 7-27.

Dess, G. G., Lumpkin, G. T., and Covin, J. G. (1997). Entrepreneurial strategy making and firm performance: Test of contingency and configurational models. Strategic of Management Journal, 18(9), 677-695.

Dev, M.S. and Mahajan, V. (2003). Employment and unemployment. Economic and Political Weekly, 38(12), 1252-1261.

Dian-Hikmah, M. I. and Mahyuddin, M. Z. (2016). Youth Unemployment in Malaysia: Developments and Policy Considerations. Bank Negara Malaysia Annual Report.

Dinis, A., do Paco, A., Ferreira, J., Raposo, M., \& Gouveia Rodrigues, R. (2013). Psychological characteristics and entrepreneurial intentions among secondary students. Education+ Training, 55(8/9), 763-780. 
INTERNATIONAL JOURNAL OF ACADEMIC RESEARCH IN BUSINESS AND SOCIAL SCIENCES

Vol. 9, No. 1, Jan, 2019, E-ISSN: 2222-6990 @ 2019 HRMARS

Doherty, B., Haugh, H. and Lyon, F. (2014). Social enterprises as hybrid organizations: a review and research agenda. International Journal of Management Reviews, 16, 417-436.

Drucker, P. (1985). Drucker Innovation and Entrepreneurship. Butterworth-Heinemann: Oxford.

Francisco, L. and Alain, F. (2015). A systematic literature review on entrepreneurial intentions: citation, thematic analyses, and research agenda. International Entrepreneurship and Management Journal, 11(4), 907-933.

Franke, N., and Lüthje, C. (2004). Entrepreneurial intentions of business students - a benchmarking study. International Journal of Innovation and Technology Management, 1, 269-288.

Gelaidan, H. and Abdullateef, A. (2017). Entrepreneurial intentions of business students in Malaysia. Journal of Small Business and Enterprise Development, 24(1), 54-67.

Gerba, D. (2012). The context of entrepreneurship education in Ethiopian universities. Management Research Review, 35(3/4), 225-44.

Granovetter, M. (1985). Economic action and social structure: The problem of embeddedness. American Journal of Sociology, 91, 481-510.

Granovetter, M. (1995). The economic sociology of immigration. The economic sociology of firms and entrepreneurs. In A. Portes (Ed.). New York: Russell Sage Foundation.

Grant, R. (1996). Toward a knowledge-based theory of the firm. Strategic Management Journal, 17, 109-122.

Greene, F. J., and Saridakis, G. (2008). The role of higher education skills and support in graduate selfemployment. Studies in Higher Education, 33(6), 653-672.

Greve, A. and Salaff, J.W. (2003). Social networks and entrepreneurship. Entrepreneurship Theory and Practice, 28, 1-22.

Hamböck, C., Hopp, C., Keles, C., and Vetschera, R. (. (2017). Risk aversion in Entrepreneurship Panels: Measurement Problems and Alternative Explanations. Managerial and Decision Economics, 38(7), 1046-1057.

Hatten, T. (2006). Small Business Management: Entrepreneurship and Beyond, 3rd ed. New York, NY: Houghton Mifflin Company.

Henderson, R. and Robertson, M. (1999). Who wants to be an entrepreneur? Young attitudes to entrepreneurship as a career. Education + Training, 41(5), 236-245.

Hoelscher, M., \& Elango, B. (2012). The impact of business climate, foreign population and unemployment on new venture creation. Journal of Developmental Entrepreneurship, 17(04), 1250021.

Hofstede, G. (1980). National cultures in four dimensions: a research-based theory of cultural differences among nations. International Studies of Management and Organization, 13(1/2), 46-74.

Hofstede, G. and Bond, M.H. (1988). The Confucius connection: from cultural roots to economic growth. Organizational Dynamics, 16(4), 5-21.

Hoogendoorn, B., Zwan, P. v., and Thurik, R. (2017). Sustainable Entrepreneurship: The Role of Perceived Barriers and Risk. Journal of Business Ethics, 1-22.

Huang, L. and Knight, A. (2017). Resources and Relationships in Entrepreneurship: An Exchange Theory of the Development and Effects of the Entrepreneur-Investor Relationship. Academy of Management Review, 42(1), 80-102. 
INTERNATIONAL JOURNAL OF ACADEMIC RESEARCH IN BUSINESS AND SOCIAL SCIENCES

Vol. 9, No. 1, Jan, 2019, E-ISSN: 2222-6990 @ 2019 HRMARS

Hvide, H. K., and Panos, G. A. (2014). Risk tolerance and entrepreneurship. Journal of Financial Economics, 111(1), 200-223.

Jack, S.L. and Anderson, A.R. (2002). The effects of embeddedness on the entrepreneurial process. Journal of Business Venturing, 17, 467-487.

Jenssen, J. I., \& Koenig, H. F. (2002). The Effect of Social Networks on Resource Access and Business Start-ups. Journal European Planning Studies, 10(9), 1039-1046.

Joseph, I. (2017). Factors Influencing International Student Entrepreneurial Intention in Malaysia. American Journal of Industrial and Business Management, 7, 424-428.

Karimi, S., Biemans, H. J. A., Lans, T., Chizari, M. and Mulder, M. (2016). The impact of entrepreneurship education: A study of Iranian students' entrepreneurial intentions and opportunity identification. Journal of Small Business Management, 54(1), 187-209.

Kerr, G., and Armstrong-Stassen, M. (2011). The Bridge to Retirement: Older Workers' engagement in Post-Career Entrepreneurship and Wage-and-Salary Employment. Journal of Entrepreneurship, 20(1), 55-76.

Kogut, B. and Zander, U. (1992). Knowledge of the firm, combinative capabilities, and the replication of technology. Organization Science, 3, 383-397.

Kuratko, D. F. (2005). The emergence of entrepreneurship education: Development, trends, and challenges. Entrepreneurship: Theory \& Practice, 29(5), 577-597.

Kuriakose, F., \& Joseph, J. (2015). Nurturing Youth Entrepreneurship To Tackle Youth Unemployment. Journal of Research Innovation and Management, 1 (1), 1-20.

Kvedaraite, N. (2014). Experience of students of Lithuanian higher education institutions. Management, 19(1), 1-16.

Laily, M. H., Hamidah, R., Nur'Ain, S., Nur-Najwa, H., \& Intan-Syamimi, S. (2017). Postgraduate Entrepreneurial Intentions Among AAGBS Students. International Journal of Accounting Finance and Business, 2(5), 1-14.

Lee, S. H., and Wong, P. K. (2004). An exploratory study of technopreneurial intentions: a career anchor perspective. Journal of Business Venturing, 19, 7-28.

Luca, M. R., \& Cazan, A. M. (2011). Involvement in entrepreneurial training and personality. ProcediaSocial and Behavioral Sciences, 30, 1251-1256.

Madrigal, B.E., Arechavala, R. and Madrigal, R. (2012). El emprendedor y su capital social: caso el clúster del software en Jalisco (The entrepreneur and social capital: the Jalisco software cluster) (2012). Revista International Administración and Finanzas, 5(4), 107-120.

Malaysian SMEs. (2017). Youth Entrepreneurship Fund. Kuala Lumpur: SME Bank.

Manjit, S. S., Shaufique, F. S., and Shoaib, R. (2011). Entrepreneurship barriers and entrepreneurial inclination among Malaysian postgraduate students. International Journal of Entrepreneurial Behaviour \& Research, 17(4), 428-449.

Martin, B. C., McNally, J. J., and Kay, M. J. (2013). Examining the formation of human capital in entrepreneurship: A meta-analysis of entrepreneurship education outcomes. Journal of Business Venturing, 28(2), 211-224.

Merle, K., Marianne, K., Urve, V., and Aino, K. (2014). Entrepreneurship education at university level and students' entrepreneurial intentions. Procedia - Social and Behavioral Sciences, 110, 658 668. 
Michael, J. M., Ernesto, H., Christopher, M., and Chee, L. K. (2016). Entrepreneurial intentions of university students in an emerging economy: The influence of university support and proactive personality on students' entrepreneurial intention. Journal of Entrepreneurship in Emerging Economies, 8(2), 162-179.

Nabi, G., and Liñán, F. (2011). Graduate entrepreneurship in the developing world: intentions, education and development. Education+ Training, 53(5), 325-334.

Nahapiet, J. and Ghoshal, S. (1998). Social capital, intellectual capital, and the organizational advantage. Academic Management Review, 23(2), 242-266.

Olugbola, S. A. (2017). Exploring entrepreneurial readiness of youth and startup success components: Entrepreneurship training as a moderator. Journal of Innovation \& Knowledge, 2(3), 155-171.

Ozaralli, N, and Rivenburgh, N. (2016). Entrepreneurial intention: antecedents to entrepreneurial behavior in the U.S.A. and Turkey. Journal of Global Entrepreneurship Research, 6(1), 3.

Packham, G., Jones, P., Miller, C., Pickernell, D., and Thomas, B. (2010). Attitudes towards entrepreneurship education: A Comparative Analysis. Education+ Training, 52, 568-586.

Radzi, N. M., Shamsuddin, A., \& Wahab, E. (2017). Enhancing the Competitiveness of Malaysian SMES Through Technological Capability: A Perspective. The Social Sciences, 12(4), 719-724.

Ramayah and Harun. (2005). Entrepreneurial intention among the students of USM. International Journal of Management and Entrepreneurship, 1(1), 8-20.

Rauch, A. and Hulsink, W. (2015). Putting entrepreneurship education where the intention to act lies: an investigation into the impact of entrepreneurship education on entrepreneurial behaviour. Academy of Management Learning \& Education, 14(2), 187-204.

Rideout, E. C., \& Gray, D. O. (2013). Does Entrepreneurship Education Really Work? A Review and Methodological Critique of the Empirical Literature on the Effects of University-Based Entrepreneurship Education. Journal of Small Business Management, 51(3), 329-351.

Robb, A. M. and Fairlie, R. W. (2006). Tracing access to financial capital among African-Americans from the entrepreneurial venture to the established business. Conference Proceedings, Research Conference on Entrepreneurship Among Minorities and Women.

Saeed, S., Yousafzai, S. Y., Yani-De-Soriano, M., \& Muffatto, M. (2015). The Role of Perceived University Support in the formation of Students' Entrepreneurial Intention. Journal of Small Business Management, 53(4), 1127-1145.

Schwarz, E. J., Wdowiak, M. A., Almer-Jarz, D. A., and Breitenecker, R. J. (2009). The effects of attitudes and perceived environment conditions on students' entrepreneurial intent: An Austrian perspective. Education + Training, 51, 272-291.

Shane, S., and Venkataraman, S. (2000). The promise of entrepreneurship as a field of research. Academy of Management Review, 25, 217-226.

Shaw, E., and Carter, S. (2007). Social entrepreneurship: Theoretical antecedents and empirical analysis of entrepreneurial processes and outcomes. Journal of Small Business and Enterprise Development, 14(3), 418-434.

Short, J. C., Ketchen Jr. D. J., Shook, C. L., and Ireland, R. D. (2010). The concept of "opportunity" in entrepreneurship research: Past accomplishments and future challenges. Journal of Management, 36(3), 40-65. 
INTERNATIONAL JOURNAL OF ACADEMIC RESEARCH IN BUSINESS AND SOCIAL SCIENCES

Vol. 9, No. 1, Jan, 2019, E-ISSN: 2222-6990 (C) 2019 HRMARS

Singh Sandhu, M., Fahmi Sidique, S. and Riaz, S. (2011). Entrepreneurship barriers and entrepreneurial inclination among Malaysian postgraduate students. International Journal of Entrepreneurial Behavior \& Research, 17(4), 428-449.

Sivarajah, K. and Achchuthan, S. (2013). Entrepreneurial Intention Among Undergraduates: Review of Literature. European Journal of Business and Management, 5(5), 172-186.

Smallbone, D., Friederike, W. and Jovo, A. (2014). Entrepreneurship in emerging market economies: contemporary issues and perspectives. International Small Business Journal, 32(2), 113-116.

Solesvik, M. W. (2014). Cultural factors and entrepreneurial intention. Education + Training, 56(8-9), 680-696.

Tenth Malaysian Plan 2006-2010. (2013). Retrieved Dec 28, 2017, from http://www.epu.gov.my/en/tenth-malaysia-plan-10th-mp-(2013)

Trivedi, R. (2017). Entrepreneurial-intention constraint model: A comparative analysis among postgraduate management students in India, Singapore and Malaysia. International Entrepreneurship Management Journal, 13, 1239-1261.

Tucker, D. and Selcuk, S.S. (2009). Which factors affect entrepreneurial intention of university student? Journal of European Industrial Training, 33(2), 142-159.

Van de Ven, A. H., Polley, D. E., Garud, R., and Venkataraman, S. (1999). The innovation journey. New York: Oxford University Press.

Van Praag, C.M. and Cramer, J.S. (2001). The roots of entrepreneurship and labour demand: individual ability and low risk aversion. Economica, 68(269), 45-62.

Vecchio, R. (2003). Entrepreneurship and leadership: common trends and common threads". Human Resource Management Review, 13(2), 303-327.

Ven, S. T. (2007). Drivers of urban entrepreneurship: an integrative model. International Journal of Entrepreneurial Behavior \& Research, 13(4), 235-51.

Vissa, B. (2012). Agency in action: Entrepreneurs' networking style and initiation of economic exchange. Organization Science, 23(2), 492-510.

Wang, C.K. and Wong, P.K. (2004). Entrepreneurial interest of university students in Singapore. Technovation, 24, 161-72.

Yusof, A. (2009). Pembangunan Modal Insan - Teras Pendidikan Negara. Sintok: Penerbit Universiti Utara Malaysia.

Zamberi-Ahmad, S. and Xavier, S. (2012). Entrepreneurial environments and growth: evidence from Malaysia GEM data. Journal of Chinese Entrepreneurship, 4(1), 50-69.

Zhao, H., S. E. Seibert, and G. E. Hills. (2005). The Mediating Role of Self-Efficacy in the development of Entrepreneurial Intentions. The Journal of Applied Psychology, 90(6), 1265-1272. 